\title{
HLA-B27 antigen in diagnosis of atypical seronegative inflammatory arthropathy
}

\author{
G. JOLIAT, A. FERRO, M. JEANNET, AND H. OTT
}

From the Service of Rheumatology and Physical Medicine, Community Hospital, La Chaux-de-Fonds, and the Division of Immunology and Allergy, University Department of Medicine, Geneva, Switzerland

\begin{abstract}
Joliat, G., Ferro, A., Jeannet, M., and Ott, H. (1976). Annals of the Rheumatic Diseases, 35, 531-533. HLA-B27 antigen in diagnosis of atypical seronegative inflammatory arthropathy. Eighteen patients with an inflammatory pauciarticular peripheral arthropathy not typical of any known entity showed an asymmetrical pattern of disease, with a predilection for the lower extremities. Destructive joint changes and deformities were absent (mean follow-up 10 years). Although spondylitis and sacroiliitis were absent on $x$-rays, HLA-B27 antigen was found in 8 patients (44\%). This antigen and similar joint symptoms are also found in other forms of arthritis.
\end{abstract}

The HLA antigens constitute the major system of histocompatibility in man (Lancet, 1975) and some of these antigens have been found to be associated with certain diseases (McDevitt and Bodmer, 1972, 1974). A clear correlation has been established between HLA-B27 and ankylosing spondylitis (Brewerton and others, 1973a; Schlosstein and others, 1973; Amor and others, 1974) and related diseases such as Reiter's syndrome (Brewerton and others, 1973b; Caughey and others, 1974; Morris and others, 1974; Amor and others, 1974), postdysenteric arthritis (Aho and others, 1974), and the spondylarthritis that can complicate psoriasis (Brewerton and others, 1974b; Metzger and others, 1975), regional ileitis (Crohn's disease), and ulcerative colitis (Brewerton and others, 1974; Morris and others, 1974b). These diseases are characterized by frequent but inconsistent involvement of the sacroiliac joints and the spine, by an asymmetric pattern of peripheral arthritis affecting the larger joints, especially of the lower extremities, and by the absence of rheumatoid factors or nodules.

Some patients have atypical forms of chronic peripheral arthritis which cannot be satisfactorily classified as a well-defined entity. In some of these patients a few joints only are involved, asymmetrically, usually of the lower extremities. Rheumatoid serum factor or nodules are absent. This study attempts to define such a form of atypical pauciarticular rheumatism and to search for an association with the tissue antigen HLA-B27.

\section{Methods}

Eighteen patients attending the Rheumatology unit, Community Hospital, La Chaux-de-Fonds, were selected for study from a clinic population of 377 patients with chronic inflammatory arthritis by the criteria given in Table I. Age, sex, and duration of symptoms are given in Table II. Laboratory tests included blood counts and smears, antistreptolysin 0 determination, latex and antinuclear factor tests, transaminases and alkaline phosphatase and all were normal. HLA-B27 was determined with the microcytotoxicity test (Terasaki and McClelland, 1964). All patients had had recent $x$-rays of the joints or part of the spine involved, and of the pelvis, with a view of the sacroiliac joints according to Barsoni. Patients with clinical suspicion of sacroiliitis had tomography of these joints.

Table I. Clinical criteria for selection of patients

(1) Inflammatory characteristics of pain: mostly nocturnal or early morning pain and stiffness with at least occasional inflammatory swelling

(2) Absence of rheumatoid nodules, rheumatoid factors, and erosions of small joints

(3) Absence of sacroiliitis or spondylitis by $x$-ray

(4) Absence of psoriasis, inflammatory intestinal disease, urethritis, and eye involvement

(5) Absence of foci of infection, degenerative lesions, or microcrystals

(6) Symptoms beginning after puberty and lasting for at least 3 years 
Table II Patients studied $(n=18)$

\begin{tabular}{lll}
\hline $\begin{array}{l}\text { Sex } \\
\text { Mean age at onset } \\
\text { (range, median) }\end{array}$ & 13 female, 5 male \\
$\begin{array}{c}\text { Mean duration in years } \\
\text { (range, median) }\end{array}$ & $26 \quad(14-49,20)$ \\
\hline
\end{tabular}

Table III Clinical characteristics of patients with atypical inflammatory arthropathy

\begin{tabular}{|c|c|c|}
\hline & \multicolumn{2}{|l|}{$H L A-B 27$} \\
\hline & $\begin{array}{l}\text { Positive } \\
\text { (8 patients) }\end{array}$ & $\begin{array}{l}\text { Negative } \\
\text { (10 patients) }\end{array}$ \\
\hline Inflammatory back pain* & 4 & 3 \\
\hline Involvement of $1-2$ joints only & 4 & 6 \\
\hline Involvement of lower limb & & \\
\hline $\begin{array}{l}\text { Joints only } \\
\text { Asymmetrical ioint pattern }\end{array}$ & $\begin{array}{l}5 \\
4\end{array}$ & $\begin{array}{l}5 \\
5\end{array}$ \\
\hline Heel pain, Achilles tendinitis & 2 & 0 \\
\hline $\begin{array}{l}\text { ESR (1st h) mean (range and } \\
\text { median) }\end{array}$ & $8(4-12,5)$ & $9(1-24,10)$ \\
\hline
\end{tabular}

*Night or early morning pain, improving with motion.

\section{Results}

Of the 18 patients studied, 8 carried the antigen HLA-B27 $(44.4 \%)$. The difference from the normal Swiss population, with prevalence of $6 \%$ of HLA$\mathrm{B} 27$, is clearly significant $(\mathrm{P}<0.005)$. The clinical characteristics of the patients are given in Table III. There was no consistent difference between the group of patients with HLA-B27 and the group without in age at onset, sex, duration of symptoms, and clinical expression. The 2 patients with heel pain or Achilles tendinitis had HLA-B27. Only half of the patients had a symmetrical pattern of arthritis affecting at least two pairs of joints. Only one patient had small finger joint involvement (metacarpophalangeal joints). Symptoms usually lasted for weeks and recurred at the same sites. None of the patients had developed deformed joints, or destructive or erosive joint changes on $x$-ray .

\section{Discussion}

The joint symptoms of the patients described here resemble the arthritis seen in Reiter's syndrome (McClusky, Lordon, and Arnett, 1974), postdysenteric arthritis (Aho and others, 1974), or in the peripheral manifestation of ankylosing spondylitis (Ravault and others, 1970). The tissue antigen HLA-B27 is frequently found in these conditions. In our patients the prevalence of this antigen was significantly raised, strengthening the link among these different conditions which is already manifest on clinical grounds. Sacroiliitis and spondylitis are not necessarily found in Reiter's syndrome
(McClusky and others, 1974) or in postdysenteric arthritis (Aho and others, 1974) and both were absent on $x$-rays in our patients. The antigeno? HLA-B27 seems to be linked as much to a peculiar kind of peripheral arthritis as to sacroiliitis or spondy- $\stackrel{\vec{P}}{\stackrel{\oplus}{\oplus}}$ litis.

Some of the patients might in time show the $\frac{\bar{\sigma}}{\bar{D}}$ missing symptoms and develop one of the better defined entities, such as Reiter's syndrome, etc. It is well known that ankylosing spondylitis, for example, can begin with minor, atypical peripheral arthritisbefore the appearence of sacroiliitis or spondylitis ${ }_{-}^{\circ}$ (Schlosstein and others, 1973). Despite a mean $\vec{\omega}$ follow-up of our patients of 10 years since onsets of symptoms, the possibility of their developing a more defined disease cannot be excluded, but it becomes less probable with time.

It is unlikely that classical rheumatoid arthritiser will develop in the majority of the patients. Most $\stackrel{\omega}{-}$ investigators who have searched for the antigen? HLA-B27 in patients with rheumatoid arthritisfound a prevalence similar to that in the generalס population (Lies, Messner, and Troup, 1972). Even though carriers of the phenotype HLA-B27 in the 3 normal population are evenly divided between the sexes, classical ankylosing spondylitis occurs more $\overrightarrow{-}$ frequently in males (Tyson, Thompson, and Ragag, 1953). Recent reports in which blood donors w? HLA-B27 were examined indicate that both meno and women can be affected by this disease at the same frequency (Calin and Fries, 1975; Truog, ̄ Dolivo, and Steiger, 1975). Still, women often haveő clinically less manifest disease. The high proportion of women in our group of patients indicates that $\vec{B}$ they might present a mild form of the seronegative 3 variant arthropathies linked together by the antigen HLA-B27.

The prognosis for this form of arthritis seems to be good, although more cases need to be studied. It $\underline{0}$ seems that these patients can be recognized within a $\frac{0}{3}$ few years of onset of the disease especially when HLA-B27 is present. Separating this group fromo other forms of arthritis would be useful, especially for prognosis and to exclude such patients froms therapeutic trials. In addition, further study of these patients might help to elucidate the relationship․ㅡ. among the different forms of seronegative inflam- N matory arthropathies.

The authors express their gratitude to Professor J.\& Fabre, Professor G.-H. Fallet, Professor T. Vischer, Dr.' L. Balant, Miss C. Amez-Droz, and Miss G. Huguenin $\frac{\square}{-}$ for technical and scientific assistance without which this $\frac{}{\mathbb{D}}$ work would not have been possible. Special thanks to Dr. B. Ruedi who permitted us to study one of his patients. 


\section{References}

Aho, K., Ahvonen, P., Lassus, A., Sievers, K., and Tillikainen, A. (1974) Arthr. and Rheum., 17, 521 (HL-A 27 in reactive arthritis: a study of Yersinia and Reiter's disease)

Amor, B., Feldmann, J. L., Delbarre, F., Hors, J., Beaujan, M. M., and Dausset, J. (1974) New Engl. J. Med., 290, 572 (HL-A antigen W27- a genetic link between ankylosing spondylitis and Reiter's syndrome)

Brewerton, D. A., Caffrey, M., Hart, F. D., James, D. C. O., Nicholls, A., AND Sturrock, R. D. (1973a) Lancet, 1, 904 (Ankylosing spondylitis and HL-A27)

,-- , Nicholls, A., Walters, D., OATES, J. K., AND James, D. C. O. (1973b) Ibid., 2, 996 (Reiter's disease and HL-A27)

$\longrightarrow,-,-, \ldots$, AND JAMES, D. C. O. (1974) Ibid., 1, 956 (HL-A27 and arthropathies associated with ulcerative colitis and psoriasis)

CALIN, A., AND Fries, J. F. (1975) New Engl. J. Med., 293, 835 (Striking prevalence of ankylosing spondylitis in 'healthy' W27 positive males and females)

Caughey, D. E., Hawkes, J. G., Mills, K. R. AND Douglas, R., (1974) Curr. med. Res. Opin., 2, 17 (Reiter's disease and HL-A27)

Lancet (1975) 2, 536 (Tissue antigen and disease) (Leading article)

Lies, R. B., Messner, R. P., AND Troup, G. M. (1972) Arthr. and Rheum., 15, 524 (Histocompatibility antigens and rheumatoid arthritis)

MCClusky, O. E., LoRdon, R. E., AND ARNeTt, F. C. (1974) J. Rheumatol., 1, 263 (HL-A27 in Reiter's syndrome and psoriatic arthritis: a genetic factor in disease susceptibility and expression)

MCDevirt, H. O., AND Bodmer, W. F. (1972) Amer J. Med., 52, 1 (Histocompatibility antigens, immune responsiveness and susceptibility to disease)

- - - - (1974) Lancet, 1, 1269 (HL-A, immune-response genes and disease)

Metzger, A. L., Morris, R. I., Bluestone, R., AND TeraSAKI, P. I. (1975) Arthr. and Rheum., 18, 111 (HL-A27 in psoriatic arthropathy)

Morris, R., MetZger, A. L., Bluestone, R., ANd Terasaki, P. I. (1974a) New Engl. J. Med., 290, 554 (HL-A W27 - a clue to the diagnosis and pathogenesis of Reiter's syndrome)

$-, \frac{1}{-}, \frac{1}{1974 b)}$ Ibid., 290, 1117 (HL-A W27 - a useful discriminator in the arthropathies of inflammatory bowel disease)

Ravault, P. P., LeJeune, E., Bouvier, M., Jeanneret, J., Meunier, P., Queneau, P., AND Robillard, J. (1970) Rev. Rhum, 73, 197 (Les formes atypiques de la spondylarthrite ankylosante (à propos de l'analyse de 236 observations))

Schlosstein, L., Terasaki, P. I., Bluestone, R., and Pearson, C. M. (1973) New Engl. J. Med., 288, 704 (High association of an HL-A antigen, W27, with ankylosing spondylitis)

TERASAKI, P. I., AND MCClelland, J. C. (1964) Nature, 204, 998 (Microdroplet assay of human serum cytotoxyns)

Truog, P., Dolivo, U., AND STeiger U. (1975) Méd. et Hyg., 23, 1889 (Etude de l'incidence des sacro-iliites chez les porteurs de l'antigène HL-A B27)

Tyson, T. L., Thompson, W. A. L., AND Ragan, C. (1953) Ann. rheum. Dis., 12, 40 (Marie Strümpell spondylitis in women) 